\title{
Creative entextualizations of discourses about race in multi-sited discursive practices in the Brazilian 'periphery'
}

\author{
Thayse Figueira Guimarães \& Luiz Paulo Moita-Lopes \\ Vale do Rio Verde University, Brazil / Federal University of Rio de Janeiro, Brazil
}

\begin{abstract}
This paper focuses on Luan's race performances both on the web and in classroom interaction. Luan is a black young man, who identifies himself as gay. The study is part of a multi-sited ethnographic piece of research on a group of high-school students in the state sector, in the 'periphery' of a town on the Rio de Janeiro State north coast, Brazil. The paper is guided by performance and entextualization theorizing. The analysis draws attention to the circulation of racial identity signs, intersected with gender/sexuality meanings, bringing to light what we call creative entextualizations, i.e. the gaps Luan finds to re-organize the meanings in the discursive practices in which he is engaged. The analyses point to positionings and innovative identity performances which come up in conjunction with essentialized views, always perceptible amidst struggles and disputes. Because it draws attention to mobile lives in the 'periphery', this study may be said to explode the traditional boundaries between 'center' and 'periphery'.
\end{abstract}

Keywords: multi-sited ethnography; Twitter; classroom; race; entextualization; performance

\section{Introduction}

Typical of contemporary social life, the processes of mobility and (de)(re)territorialization which are said to be a result from our globalized times have become crucial factors to understand the enormous changes we have been experiencing in our everyday social relations. If globalization is indeed associated with a significant change regarding the mobility of people, objects, linguistic and cultural resources, its consequences, among others, are the increasingly close links between localities and global fluxes, which are said to account for our translocal lives (Appadurai, 1996; Blommaert, 2010). With this perspective as background, this article investigates the circulation of discourses about race in multiple discursive practices, prioritizing the interconnectedness, through 
several knots, of apparently different and distant phenomena, in the construction of translocal meanings.

The analysis will draw on ethnographic research involving a group of highschool students in a state school in the 'periphery' of a town on the north coast of the state of Rio de Janeiro, Brazil. This ethnographic investigation took into account those students' discursive actions both at school and in online social networks, on Facebook and Twitter. It centers on a multi-situated or multilocal perspective (Marcus, 1995), in which the researcher follows the chains, the trajectories and the threads of meanings constructed in social practices by focusing on a particular phenomenon being investigated. This research process is thus based on the juxtaposition of social sites, where students' discursive practices are lived and where the researcher is involved with tracing connections (Wittel, 2000) between such spaces and practices. The object of a multi-situated investigation is defined through the use of different research moves. Following the social practices and the cultural artifacts of a group or of a person and their stories is, according to Marcus (1995), a way of making such an approach possible.

In this article, we follow the texts and discourses constructed by one of the student-participants in this research project, whom we will call Luan: a young working-class gay black man. We will focus on how Luan constructs his racial performances in different interactional contexts. We study his discursive practices both at school and on Twitter, particularly centering on how he copes with body-related meanings, normativity matrices, social stereotypes and marginalized alterities in the negotiation of his identity performances. The investigation of the circulation of racial identity signs is carried out with an eye on the intersection of gender and sexuality meanings (Barnard, 2004; Sullivan, 2003), paying special attention to what we call creative entextualizations, i.e. the gaps Luan finds to reorganize the meanings in the discursive practices in which he engages himself. Therefore, we will follow Luan and his engagement in discourse at school and in the social network flows of globalization. We argue that Luan's entextualization of the repetition of stereotypical racial signs is productively realized through a micropolitics (Foucault, 1979) which challenges privileged positionings in his inter-racial relationships with his friends at school and on Twitter.

\section{Race as performative}

Understanding identity constructions as performative is crucial to how we theorize race. We follow Butler (1990) and her account of a performative theory of gender and sexuality. According to Butler (1990), people continually repeat 
performative acts of 'masculine' and 'feminine' gender and their performative efficacy impedes the identification of the original foundational point of such identities. Her aim is to denaturalize sexual/gender difference by observing how gender and sexuality are constructed by the uses of the body (Preciado, 2010). She uses the construct of performativity, incorporating Austin's and Derrida's perspectives on speech acts, to declare that language which refers to the body not only describes it but, at the very moment of naming it, constructs that which is named.

Following this kind of argument, gender is performative because its enunciation constitutes the identity it intends to be (Butler, 1990). For Butler (1990: 173), the idea that "the gendered body is performative suggests that it has no ontological status apart from the various acts which constitute its reality". It is a social, historical, cultural and discursive construction. She argues that gender is not an expression of an essential part of the body, that is, "there is no gender identity behind the expression of gender, [...] identity is performatively constituted by the very 'expressions' that are said to be its results" (Butler, 1990: 33).

From this point of view, gender is the effect of a repeated stylization of performance. Butler (1990) claims that 'masculinity' and 'femininity' neither refer to what we are, nor to features which are inherent to us. They are discursive effects produced by the things we do, say and dress in our everyday performances. It is in the repeated citation of the socially constructed norms, in their iterability, that gender (and identifications in general) acquire the appearance of solid and immutable substance (Pennycook, 2007). Butler's perspective dismantles the connections which supposedly assign to gender, sex and desire an intrinsic essence or a biological substrate. If performance only exists when it is enacted, it cannot be reduced to an essential nature. There is always the possibility of performing differently, despite the fact that there are constraints regarding the inauguration of new meanings. Certainly, the crucial constraint in relation to the creation of innovative gender/ sexuality meanings is derived from the appearance of naturalness that heteronormative life itineraries have in common sense, which makes alternative meanings problematic because they speak to an unauthorized 'form of life', ranked as inferior, abject and less human.

By interrogating the historically normative meanings of gender through the use of the notion of performative, Butler provides us with a philosophical basis which allows us to question other socio-historically sedimented meanings. For example, racial discourses which have been historically positioning blacks as inferior. The notion of performative then has relevant implications not only for gender and sexuality identifications but also for the racialization of subjectivities (Costa de Paula, 2010). Race as well as sexuality came about as classificatory 
concepts between the 17th and the 18th centuries, which are constitutive of our social lives until today.

The popularization of such ideas during the Enlightenment fomented a crescent increasing preoccupation with racial purity and the fear of miscegenation. It is not difficult to understand how the racialization of the world has socially placed a lot of individuals in subaltern positions all over. Race is a biological attribute and a crystallized social positionality still present in the social imagination, supporting the superiority of one socially-constructed racial group over another. In particular, racial discrimination against blacks, their unequal economic conditions and stereotypical images of Africa typically remain unchallenged common sense.

In accordance with Guimarães (2003) and Costa de Paula (2010), we understand that race are discourses about the social origin of a group which are continually repeated in social practices when people are positioned in terms of physical features, moral and intellectual qualities etc. These processes of materialization of the black body, for example, are derived from insistent and repetitive meaning-making practices (stereotypes, statements, jokes and racial myths) which construct a field of intelligibility for this body. Like gender and sexuality, race is a discursive effect, i.e. a concept which acts by means of crystallized racist discourses in the making of individuals, their bodies and their ways of living (Bhabha, 2007[1994]). This theoretical perspective opens the possibility for abandoning sedimented meanings about races, mainly those discourses that construct blacks as having a clear-cut racial and essentialized definition, beyond their historical, social and local peculiarities (Costa de Paula, 2010; Guimarães \& Moita-Lopes, 2016).

Therefore, race is also the materialization of a performative discourse, which is not disassociated from the materialization of gender and sexuality. That is the reason why several theoreticians have emphasized the relevance of studying the intersectionalities of gender, sexuality and race - a view derived from Queer Theories (Sommerville, 2000; Sullivan, 2003; Barnard, 2004; for example). The issue is not related to the specificity of racial or ethnic oppression as another variant side by side with sexuality and gender oppression. What is relevant is to focus on the analysis of the performative mutual constitution of gender, sexuality and race, which is understood as "the sexualization of race and the racialization of sex" (Preciado, 2010: 52). This is a fundamental theoretical point in understanding Luan's identity performances: a young black man who positions himself as gay in his online social networks and at school. Thus, by focusing on Luan's race performances, we are interested in how the young man operates with identity signs of gender, sexuality and race when engaging in communicative practices both in the classroom and on Twitter. 


\section{The contextualizing nature of discourses}

When discourses materialize themselves in texts, they undergo successive processes of entextualization. As Blommaert (2005) has argued, texts travel by following trajectories through different contexts. This view involves the fact that a " piece of text" or "excerpt", as a semiotic object, may be extracted from its original context of use and materialized in a new context (Varis \& Blommaert, 2014). It also underlines the fact that, when a 'same' text is transported beyond its 'original' context, it undergoes ample processes of change in the construction of meanings (Blommaert, 2005).

In this sense, discourses materialized in texts are likely to be removed from their original interactional/contextual environment and replicated in another, becoming another text and so on (Bauman \& Briggs, 1990; Blommaert, 2010). The text is remodeled, renarrated, reframed and the entextualization becomes the textual travel itself. According to Silverstein and Urban (1996), this process in general terms is part of "the natural histories of discourses". When transported, texts are negotiated through interpretative processes on the basis of social and historical stabilized systems. Specific interpretations then come about and texts are renarrated and reframed in the interactional encounter, constituting certain webs of meanings repeated over time. The focus on language in use is thus widened beyond circumscribed specific communicative events so that we can study texts following multiple trajectories. Textual mobility can then account for new interactional contextual interpretations each time entextualization-decontextualization-recontextualization and identity signs (Wortham, 2006) are in action.

The entextualizing and mobile dimension of these semiotic resources, culturally available, help us understand, in dialogue with Butler (1990), that identity performances are "the repeated stylization of the body" (p. 43). Therefore, Luan's identifications are constituted by successive repetitions of identity signs (Wortham, 2006), which, through entextualization, are transported from one context to another (Silverstein and Urban, 1996). In this trajectory, it is possible to visualize language performativity being enacted since, in this textual journey, textual traces of previous contexts are kept, at the same time, that novelty, creativity and change in meaning may flourish (Pennycook, 2007).

This perspective thus rejects a simplified linguistic description or analysis which operates only within the semantic and linguistic textual borders. Therefore, when focusing on the circulation of discourses about race in Luan's interactional moves, the issues considered are not only the semiotic resources used in his own interactions (for example, as it will be seen, in his post on Twitter in the next section), but also how these semiotic units construct contexts which 
produce translocal historical, cultural, political and identity relations. In other words, how these pieces of texts circulate and are recontextualized in different interactional contexts, oriented by translocal fluxes (Blommaert \& Rampton, 2011). Therefore, what matters is to understand how social subjects accept, respond to and refute such texts in circulation, i.e. how participants in the interactional practices adhere to texts produced by Luan and to evoking identity signs. In order to better understand Luan's entextualizations, we next introduce the multi-situated nature of this investigation, seeking to highlight contextual features and methodological issues.

\section{Notes on the research context, on Luan and on methodological procedures}

A part of this research took place in a school in the state sector, situated in the 'periphery' of a town in the northern coast of the state of Rio de Janeiro, Brazil. We managed to get into this school after talking to the school principal at the beginning of 2011. During the ethnographic research, the group most receptive to one of the researchers ${ }^{1}$ in the classroom and also to the virtual world in general was one of the senior morning groups, which we will refer to as Group Y. In this group, one of the students, Luan, drew our attention because of his identity performances both at school and in the social networks, which we were allowed to follow, and also because of the performative fights in which he engaged in the construction of gender, sexuality and race.

Luan was then 18 years old; besides being a Twitter user, he was also registered on Facebook, Orkut, Tumblr, MSN and Youtube. In these social networks, Luan made recourse to multisemiotic resources, which provided him with a quite differentiated profile in his group. He was very much familiarized with social networks and therefore with the flows of globalization, despite the fact that he was both geographically and socially placed in the 'periphery' of a small town in the interior of Brazil. His profile combined the use of photos which involved image edition and montage techniques, focusing on parts of his body, such as his eyes, mouth and chest. His textual description (see his self-description below in Excerpt (1)) relates to the edited images and to all the other interactional resources on the page, such as tweets (his posts), the number of tweets, the number of people following him and his followers (see Figure 1 below). Such a profile construction is carefully designed and it displays how skilful he is as a digital world user.

1. The research reported on here builds on Guimaraes' $\mathrm{PhD}$ thesis (2014). 


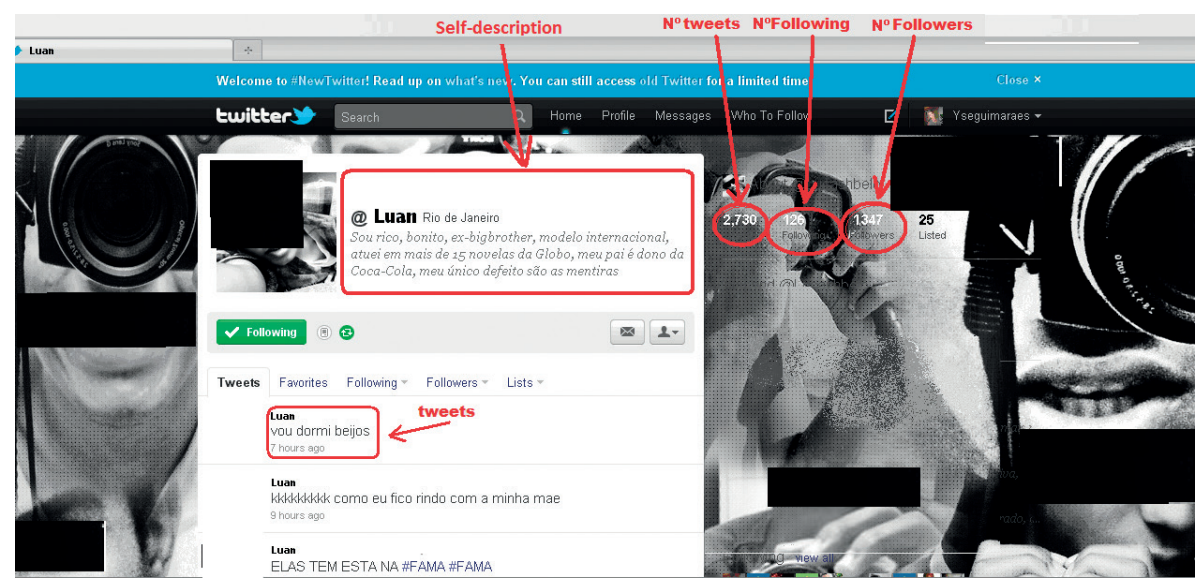

Figure 1. Luan's Twitter Profile

\section{Excerpt 1. Luan's self-description}

@Luan Rio de Janeiro ${ }^{2}$

I am rich, attractive, ex-big brother, an international model, acted in more than 15 GLOBO TV soap-operas, my father owns the Coke Company, and lies are my only problem.

His posts met the expectations of a type of sociocultural community on Twitter, i.e. that of those who want to become popular, by having a great number of followers. Luan is followed by 1347 persons, a number which is considerably greater than that of those he follows (126). Also, the number of tweets he had sent out until then was large: 2730 . Such semiotic cues signaled a profile type which is typical of popular Twitter users: several followers, but followed by few people and a lot of sent/read posts. In addition, he posted sensuous photographs of himself, which focus on his body parts, and highlighted how he is usually identified in that social arena: a sensual person. This association is very common with celebrities, who have their images displayed on magazine covers or online sites. Also, in his selfdescriptive text above Luan makes use of linguistic resources which parody the performances of celebrities. He inserts elements pointing to higher social status voices, which circulate in the international social networks, in opposition to the voices of common people like himself. The reference to his social status ("rich"), to his looks ("attractive"), to his fame ("ex-big-brother", "international model", a soap-opera actor) signal the social values which guide the discourses he mobilizes

2. All the data included in this article were written or spoken in Portuguese and have been translated into English for the purpose of this paper. 
in the SpaceTime scales of that interaction although he lets the reader know he is lying ("lies are my only problem"). The parody is thus made explicit. The combination of such resources highlights his metapragamatic awareness of the game he is playing, which allows him to reflexively position his discursive actions in the events and to construct himself as a popular person in this territory.

Luan also used Facebook a lot, posting messages and photos continually (See Figure 2 below). In this social network, his identity performances also included his positive and daring self-description (see Excerpt (2) below). The pictures were also edited in such a way that the attention focus was on his body (Figure 2 below). They helped to constitute an interactional ethos, which prioritized sensuality as in his Twitter ethos above.

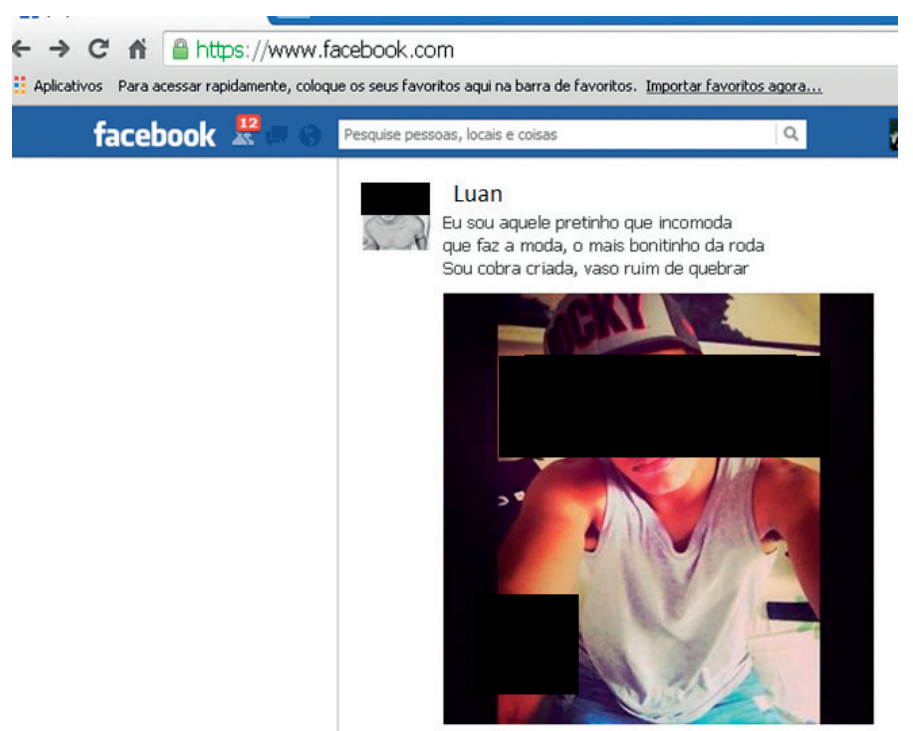

Figure 2. Luan's Facebook Profile

Excerpt 2. Facebook self-description

Luan

I am that black guy that bothers people, one who is fashionable and is the most goodlooking in the gang. I know I am a trickster and it is difficult to get rid of me.

This post generated a lot of likes and comments about his gender, sexuality and race identifications, a response to the way he publicized himself. In the Facebook profile above, Luan enacts a performance which brings about particular identification discursive effects. Here, Luan is an attractive young black man. This intersectionality is present throughout his interactions. His publicization of his body as 
desirable and beautiful corresponds to the very expectations in online spaces, in which there is a tendency to overvalue looks and body images. In this space, what matters is to be seen. Furthermore, Luan was on MSN and on Skype almost every day to contact people. He was proud of having more than 2000 friends on Skype and on MSN, almost 2000 friends on Facebook and 1347 followers on Twitter, as already mentioned. However, in the classroom his participation was virtually none.

From the beginning of this investigation, we noticed that Luan was more used to the online interactional ethos than to that of schools. This fact was continually criticized by the teachers as Luan points out in the interview data. Also, in our ethnographic observations we could see that Luan's participation in the classroom was strongly criticized by Renan, the writing teacher, as well as by other teachers, who blamed Luan's poor achievement on his intense use of the social networks. This was mainly so because Luan's participation in school literacies did not take into consideration what teachers counted as literacy, i.e. writing in the so-called 'standard Portuguese'. Therefore, his grades were low and he was constantly reprimanded. He did not participate much in classroom discussions although he was a prolific participant in the online social networks as above noted. The young man sat at the back of the room, close to one of the researchers, which made it possible to hear his whispered comments and his interactions with his classmates. ${ }^{3}$

On the basis of the theorization of performance and of the dynamics of entextualization as well as of the data generated in both ethnographic spaces (classroom and Twitter), we now focus on the analysis of Luan's performance identifications. We will take into account that in the virtual world identifications are constructed with a variety of people. Such a characteristic makes the network contexts more dynamic, unpredictable and contingent. Our analysis sheds light on the interactional moves in which Luan negotiates his black corporeality, beauty and whitening processes both in the classroom and on Twitter. We have particularly selected these scenes because they draw attention to Luan's performative struggles in the construction of meaning effects around his body and race identifications, taking into account both social constraints and his individual agency.

3. The data were generated for 10 months (from March to December 2011) through the following procedures: observations of the interactions in Group y, observations of Luan's interactions on Facebook and on Twitter, audio-recording of classroom interaction, filing of interaction in the social networks, field notes which were transformed into diaries, reports by teachers and students and individual interviews. 


\section{Analysis of entextualizations: Luan's race performances in discursive practices}

By focusing on how Luan entextualizes discourses about race in both digital and school literacy practices while constructing his identity performances, we reflect on how he projects meanings about his black body and how he recognizes himself as belonging to a race. What is relevant is therefore how Luan acts in the ways that are required by these identifications in specific communicative practices.

In the analysis of these discursive practices, we will take into account contextualization cues (Gumperz, 2002 [1982] and footings (Goffman, 2002 [1979]). Contextualization cues are, in wider terms, all the verbal and non-verbal signs which allow contextual / indexical signaling through which participants in an interaction can understand what is going on since contexts are not given. As discussed below, we reread contextualization cues in terms of their indexical values by following Collins (2011). Thus, any linguistic and non-linguistic cues (for example, gestures, body postures etc.), which contribute to signaling contextual presuppositions, may have contextualization effects.

Therefore, contextualization cues account for the communicative strategies used by interlocutors to metapragmatically indicate how they want to say what they say and how they want it to be taken. The meanings of contextualization cues can only be understood in the interactional contextualization process. Bauman and Briggs (1990), from a similar perspective, also draw attention to the relevance of focusing on the contextualization of performances. ${ }^{4}$ In reference to the notion of contextualization cues, Bauman and Briggs (1990:69) argue that "performance-based analysis has a key role to play ... in that poetically patterned contextualization cues are highlighted in performance". Consequently, their studies have focused on "the textual details that illuminate the manner in which participants are collectively constructing the world around them" (Bauman \& Briggs, 1990: 69), which implies a view of performance also centered on contextualization.

4. Butler follows an Austinian and Derridian view of performative / performativity to understand how we do gender performances as above discussed. However, Bauman and Briggs (1990), in linguistic anthropology, use the concept of performance to refer to narrative events which are different from other communicative events because they involve artful performance (the expressive or poetic function of the narrative practice). According to Bauman and Briggs (1990), poetic function draws attention to the situated linguistic action. Both perspectives, however, center on the emerging aspects of performance events, particularly on the cultural experience. 
In the analysis of face-to-face interaction, Gumperz (2002 [1982]) listed a set of cues which have the function of contextualization. Among others are: code switching, prosody, lexical and syntactic choices, paralinguistic choices etc. Although this author focused on face-to-face interaction, we argue that such cues have theoretical-analytical potential in the interpretation of online interactions. However, as Wittel (2000) posits, some of the typical cues of face-to-face interaction are accessible in virtual spaces although other types need to be considered. For example, it is necessary to pay attention to the contextualization functions of emoticons (graphic images such as hearts or sad/happy faces, among others, which express some kind of emotion), hashtag (\# preceding a word to signal a label), expressive marks such as punctuation, capital letters, colorful letters etc. It is an open, possibly unending, list in view of all the kinds of semiotic resources that interlocutors may use in these interactions.

Contextualization cues are crucial in the understanding of footings projected by participants both on online and face-to-face interactions although Goffman (2002 [1979]), like Gumperz (2002 [1982]), had the latter in mind. A change of footing occurs when a participant's alignment, positioning, or projected ' $\mathrm{I}$ ' is somehow in question. In other words, interlocutors realign themselves in interaction when they readjust their participation status. The observation of a set of projected footings may make possible the analysis of race discourse entextualizations, culturally sedimented in Luan's interactions, when he is negotiating legitimate meanings in his interactions and identity performances. In these relations, power and asymmetries between participants may give rise to struggles in the process of crystallizing legitimate meanings and may directly impact on how semiotic resources are mobilized (Silverstein and Urban, 1996).

Finally, in accordance with Collins (2011), we argue that contextualization cues - a theoretical construct which focuses on microinteractional details - may be fundamental to investigate macrosociological phenomena. Like Collins (2011), we believe that the analysis of contextualization cues may contribute to research which focuses on meaning-making processes which go beyond the limits of locally-situated interactions because of their indexical values. As Blommaert and Maly (2014:4) argue, "[...] indexicality is the dimension of meaning in which textual features 'point to' (index) contextually retrievable meanings". That way we understand that such a construct highlights the complexity of the interactional processes, in which lexical, grammatical, phonological, intonational, voice quality, alignment, intertextual choices, among others, i.e. linguistic, paralinguistic and discursive choices, are in indexical inter-relation with socio-historically sedimented meanings. 


\section{An interaction on Twitter}

The excerpt below was taken from an interaction between Luan and Moreira, one of Luan's classmates. Moreira, a white male adolescent, who positioned himself as heterosexual in classroom interaction and on the Internet, was often commenting on Luan's posts. Luan, however, when interviewed in the research, consistently stated that Moreira was a closeted gay man. The section below shows Luan negotiating meanings about his own race performance by responding to an issue raised by Moreira. According to our ethnographic observations, Moreira frequently kept an eye on Luan's race performances both on Twitter and Facebook, mainly in relation to the photos Luan posted (edited with Photoshop). Moreira qualified them as attempts on Luan's part to whiten himself. In an interview in connection with this issue, Luan stated: ${ }^{5}$

People talk to me on the Internet and they say: "look at the black man". They criticize my photos because black men are expected to be like what they see on TV. Like the black man is poor, ugly; blacks are thieves. They think that because I dress well, I know how to fight their arguments, that I want to look white; I don't feel any kind of threat in relation to my color. I take their points as a joke, but I think nobody has forgotten the way blacks were treated in the past, they think that there is still a superior race.

(Luan's interview - October 14, 2011)

Such a statement points to what Luan believes to be their classmates' racialization processes of himself at school and on Facebook, Twitter and Skype. Here he evokes socioculturally sedimented meanings about racial differences and contests the racialized meanings imposed by naming references and stereotypes. The interview took place at a point in the research process when the interviewer already had a close and trusting relationship with Luan. Therefore, he felt he could talk freely to her about the difficulties he faced with his classmates.

Next, we explore a Twitter interactional sequence in which Luan negotiates valid meanings about his race with Moreira. Despite the fact that Twitter is an open conversation with all participants, by answering the question "what are you

5. The interview data with Luan, in Portuguese, are as follows:

"Pessoas conversam comigo na Internet e fala: olha o neguinho. Fala/criticam minhas fotos porque acham que neguinho é essa coisa que mostram na TV. Tipo o negro é pobre, feio, negro rouba. Acham porque me visto bem, sei debater com eles, discutir que quero parecer branco. Não sinto nenhuma ameaça sobre esse tipo de atitude com relação a minha cor. Eu levo na brincadeira, mas acho que ninguém esqueceu o tratamento dado aos negros de antigamente, eles acham que ainda existe uma raça superior." 
doing", Moreira addresses Luan directly. The interaction took place on June 21, 2011 and it must be analyzed from bottom to top, i.e. from tweet 1 to 4 .

\section{Excerpt 3. Interaction on Twitter between Luan and Moreira ${ }^{6}$}

tweet 4 Luan@Moreira if you don't like my color tone, blame it on your bad taste... now you should stop stalking me. [Luan actually uses a Portuguese/ English version for the word stalk: "stalkeando"]

tweet 3 Luan MY RACE IS MADE WHATEVER WAY I LIKE!

tweet 2 Luan @Moreira I am not ashamed of my COLOR, I am FUC... attractive I AM PROUD OF BEING BLACK!

tweet 1 Moreira @Luan Hi devil, you have prejudice against yourself, you post black/ white photos to look attractive and to negate your color?

Each tweet is an entextualization through which the tweeter projects a footing for himself/herself at the same time that he/she positions the other and himself/herself about what they are discussing. In tweet 1, Moreira interpellates Luan in connection with his race performances, positioning himself as critical of Luan's enactment. This alignment is signaled by the word "devil"- "exu" in Portuguese -, which is how the devil is referred to in Afro-Brazilian religions. Such a lexical choice indexes Luan both as black but also as someone that has particular bewitching powers. Furthermore, Moreira associates, with race negation practices, the black/ white photos which were whitened when edited and shared in the social networks by Luan. Therefore, Moreira's lexical choices signal a classificatory discourse based on colors, through which he points to how Luan negates his black corporeality, but perhaps such choices may also signal how Moreira is bewitchingly (sexually) attracted to Luan.

Moreira's enunciation presupposes that Luan posts black and white photos so that he approximates himself to whiteness supremacy aesthetic standards. It draws attention to crystallized race discourses by transforming a possible relaxed conversation about the photos posted by Luan into a motive for struggle. Further,

6. This interaction was translated from the following data in Portuguese:

tweet 4 Luan@Moreira se não gosta de minha tonalidade, o problema é seu que tem mal gosto... Agora ficar me stalkeando...

tweet 3 Luan MINHA RAÇA É FEITA DO JEITO QUE EU QUISER!

tweet 2 Luan@Moreira eu não tenho vergonha da minha COR. Sou bonito pra CRL...

TENHO ORGULHO DE SER NEGRO!

tweet 1 Moreira@Luan Oi exu,vc tem preconceito contra vc, posta foto p/b para ficar bonito e negar sua cor? 
Moreira's words point out that the constraints on the transgressive potential of Luan's performances is related to what is socially established by common sense as 'natural facts' about black corporeality. Therefore, if Luan 'fails' in conforming to racial sedimented discourses, he somehow has to account for that. Such an issue is made clear by the opposing footing that Luan projects on the interaction: "Moreira I am not ashamed of my COLOR, I am FUC ... attractive. I AM PROUD OF BEING BLACK!" (tweet 2)

In the first part of the statement, Luan enacts an assertive posting, predicating himself as someone that has no problem with his color. The relevance he attributes to it is signaled by capitals. He also predicates himself as very good-looking and chooses an intensifier "FUC..", which is again capitalized. The second part of the statement in capitals further indicates Luan's positive evaluation of his race performances. Luan entextualizes discourses which mobilize black race positive assertiveness practices to refute Moreira's enunciation in tweet 1 . Luan points to his awareness of the fact that he needs to be ready to respond to naturalised discourses about black corporealities, which regulate what black bodies can perform. By doing so, Luan legitimates his race performances through the black and white photos he posts in the online social networks, simultaneously positioning Moreira as ignorant, simplistic and unrefined in relation to identity practices.

Furthermore, in the following post, when Luan enunciates that "MY RACE IS MADE WHATEVER WAY I LIKE!" (tweet 3), he emphatically (note the capitals) indicates that his blackness is not a ready-made package and that it can be performed outside the script Moreira's eyes want to impose on it. Performatively, Luan makes us understand that there is not an original behind his race performances that he is copying. This is a reflexive alignment that draws our attention to a comprehension of race as an effect of discourse practices in the same way that Butler (1990) argued that gender and sexuality are performative.

In tweet 4, Luan also makes recourse to other semiotic resources which project a confrontational footing. The lexical items "color tone" refer to his black corporeality and are used in the statement "Moreira if you dont like my color tone, blame it on your bad taste...now you should stop stalking me .... The use of the condition marker "if" in "if you don't like ... blame it on your bad taste" projects a footing of indifference on Luan's part towards the idea that his black performances do not please Moreira perhaps sexually. Further, the items "bad taste" used to predicate Moreira's aesthetic-sexual preference is also an important cue to understand Luan's alignment in opposition to Moreira's racialized discourses about beauty, which aim at fitting Luan into stigmatized inferior positionings. However, as said above, Moreira may actually be hiding his sexual interest in Luan under this surface counter-positioning. 
Oriented by this confrontation, Luan refers to Moreira with the following statement: "now you should stop stalking me ..." (tweet 4), which in the context of online interactions in Brazil is used to mean that one (Luan) is aware of how another participant (Moreira) has been trying to discipline one fiercely. "Stalking" then cues how Luan understands Moreira's questioning of his black corporeality. This is relevant here because this lexical choice shows how Luan is proficient in the use of proper resources in Twitter literacies (i.e. "stalkeando") in the construction of a contestation footing as regards Moreira's performances. It is also interesting, in this connection, to note how words such as "color tone", "race", "color", "black" and "am not ashamed of" and "am proud of" are repeatedly used by Luan to signal how he emphatically questions Moreira.

Next we move into the consideration of the performative effects of the entextualization of such discourses in an interactional practice in the school context. Through the use of a text brought to classroom by the writing teacher, Renan, Luan again negotiates meanings about his black corporeality, beauty and whitening processes through the use of racialized discourses.

\section{A classroom interaction}

In this section, we look into a school literacy practice, in which Luan, together with other students, participates in a pedagogical activity proposed by Renan. The activity required that students discussed different types of genres (lyrics, jokes, news articles etc.), which focused on the human search for beauty. The texts were given to the students who had to read and discuss them and then present the main points of the text to the class. The aim of the activity was to discuss young people's dissatisfaction with their bodies and their uncontrolled search for beauty as well as for the perfect body in contemporary life. The text which Luan was supposed to comment on was an article from a news web site, entitled "Poor Jamaicans risk their lives to whiten their skin". The text was about a common practice among black people in the slums of Kingston, capital of Jamaica, i.e. whitening their skin through chemical products.

In Excerpt (4) below, we transcribe a section of the talk about the text, in which Luan discusses the case of pop star, Michael Jackson, to illustrate a skin whitening practice. We consider the performative effects of such entextualization of the text in this literacy practice and the manner though which Luan, in conjunction with his classmates and the teacher, renegotiates Jackson's race identifications. Among other participants in this interaction were Bruno and Janaína (students, who positioned themselves as black male and female, respectively), and Renan 
(a white male teacher) and Ari (a white male student). See Appendix for transcription conventions.

\section{Excerpt 4. A classroom interaction ${ }^{7}$}

12 Renan: which famous example we find in the media (.) related to this discussion?

13 Bruno: that of the poor?

14 Renan: NO, that of whitening themselves.

15 Class: ((silence followed by indiscernible voices))

16 Class: michael jackson

17 Bruno: michael jackson

18 Renan: exactly. it was a disease, wasn't it? he lived through this situation.

19 one thing is your skin to be changed by a disease (.)

20 but why did he go through surgery to change his nose shape?

21 Janaína: BECAUSE WHITE PEOPLE DON'T HAVE A BIG NOSE

22 Renan: EXACTLY. so, in the end he may have used the disease as an excuse, right?

23 Luan: I think it was a disease. he was proud of his African blood

24 Class: @@@

25 Luan: he had vitiligo

26 Renan: you think so? ((indiscernible voices))

27 he went through so many surgeries and in the end he was not the same person $=$

28 Ari: $\quad=$ he thinned his nose

29 Luan: it was the disease itself

30 people criticize him $>$ because they always think that blacks want to look white<

7. The interaction in Portuguese is the following:

12 Renan: que exemplo grande a gente tem na mídia (.) dessa discussão?

13 Bruno: de pessoas pobres?

14 Renan: NÃO, de querer ficar branco.

15 Turma: ((silêncio seguido de fala tumultuada))

16 Turma: maycon jackson ((fala não identificada))

17 Bruno: maycon jackson

18 Renan: exatamente. foi doença, né? ele viveu essa situação.

Janaína: uma coisa é a doença modificar a pele (.) mas porque ele fez cirurgia pra mudar o formato do nariz?

\section{Renan:}

Luan: PORQUE BRANCO NÃO TEM NARIZ GRANDE

Turma:

EXATAMENTE. então, no fundo ele pode ter se aproveitado da doença, né?

Luan: eu acho que foi a doença mesmo. ele se orgulha de seu sangue africano

Renan: @@@@@@@

\section{Ari:} foi o vitiligo será? ((fala tumultuada)) ele fez tantas plásticas e no final não era a mesma pessoa= =afinou o nariz foi a doença mesmo o povo critica $>$ porque sempre acha que o negro quer parecer branco $<$ 
Like in the Tweet interaction above, one must have in mind that while a participant projects a footing for himself/herself, he /she is also positioning his/her interlocutor and himself/herself about what is being talked about. Between line 12 and 22, Renan introduces the discussion of the text read by Luan. He presents the corporeal transformations of the American pop singer Michael Jackson. In lines 18-20, Renan makes recourse to rhetorical questions "it was a disease, wasn't it?" (1. 18) and "but why did he go through surgery to change his nose shape?" (1. 20). In these questions, the lexical item "disease", in reference to the changes on the singer's skin, is used in opposition to the lexical item "surgery", which refers to the intentional modifications Jackson undertook. These linguistic cues signal a situation of ambiguity in relation to the whitening of the singer's skin, which projects footings of doubt and distrust for Renan or perhaps a reflexive footing. One may say that Renan offers an interpretation which justifies the depigmentation of Jackson's skin because of vitiligo; however, the nose plastic surgery indicates that the artist wanted to follow the aesthetic canons of whiteness.

This semiotic construction seems to have been understood by Janaína. Ratifying the teacher's footing, she states: "BECAUSE WHITE PEOPLE DON'T HAVE A BIG NOSE". The higher volume in voicing the sentence is a cue which signals how sure Janaína was about her point. In Brazil, skin color, hair texture and nose shape are culturally shared elements which construct people as black or white. Janaína, a black girl, is familiar with these signs and her animator footing entextualizes discourses which ratify essentialist views of blackness. Renan, in an agreement footing, states in a higher volume, EXACTLY (1. 22), and aligns himself with Janaína's point of view, by ratifying the discourse she entextualizes. Immediately afterwards, Renan finalizes his argument by enunciating "so, in the end he may have used the disease as an excuse, right?" (1. 22). In this turn, Renan constructs a distrust footing in relation to how the singer may have used the disease as an excuse for the plastic surgeries and for whitening his skin. Simultaneously, Renan constructs the singer performatively as someone that negates his own race. In his argument, Renan appropriates media discourses, in which it is supposed that Michael Jackson wanted to look white and, at the same time, Renan signals a race matrix which serves to measure who is truly black or not.

However, contrary to Renan's alignment and defending Michael Jackson's performances, Luan projects an evaluative footing, signaled by the epistemic modalization cue "I think" in the assertion "I think it was a disease."(1. 23). Luan also makes recourse to an evaluative assertion in "he was proud of his African blood" (l. 23) to redefine Michael Jackson's performances projecting for the singer a footing of people who do not negate their race and actually feel positive about it. Further, the lexical items "African blood" signal the artist's African ascendency and race discourses which refer to the origin of a race by reference to a supposedly different 
kind of blood. Luan in these entextualizations racialize the singer's performances in opposition to Renan's footing for Jackson as someone who negates his race.

In this argumentative game, the pupils' laughter in the next interactional move (1.24) are non-verbal cues which indicate a mockery footing in relation to Luan's words. Nevertheless, Luan does not seem to be bothered and continues his argument by emphasizing that Jackson's white looks were caused by vitiligo (1. 25). Here, "it was vitiligo" signals an epistemic modalization which constructs a footing of somebody that is familiar with Jackson's life and performances. Luan's statement points to the fact that he is sure that it was the singer's depigamentation that caused the problem and again emphasizes his positioning in defense of the singer. Next, Renan through the question "you think so?" (1. 26) projects a distrust footing which once again signals the idea that the vitiligo disease was only an excuse for the changes in the singer's body. In this argumentative game, Renan still states that "[Jackson] went through so many surgeries and in the end he was not the same person $="(1.27)$. In this evaluative footing, Jackson is redefined as a different person due to the "so many surgeries" which cue the intentional surgery processes he faced. To this point, Ari at the same time says that "=[Jackson] thinned his nose" also in reference to the plastic surgeries he undertook, emphasizing again that Jackson is not happy with his corporeality. The contiguous interactional move seems to signal Ari's support of Renan's footing.

In the next interactional move, by asserting that "people criticize him $>$ because they always think that blacks want to look white $<$ " (1.30), Luan again reaffirms his alignment in defense of the singer's performances. The emphasis in "people criticize him" signals the exercise of power in the social construction of the black body. Besides this, the lexical choice "always" indicates that black bodies are continuously being disciplined.

It is worth noting that in this excerpt, Renan entextualizes racialized discourses which presuppose that Jackson's race performances are strictly related to body skin, big lips, and large nose shape. In this perspective, what is at play are crystallized discourses about race differences, derived from views which restrict race identifications to phenotype traits (skin color, hair texture, body shape and face), which are taken as typical of blackness. Because Michael Jackson's performances do not correspond to such identifications, they are taken as performances of a person who negates his race. The struggles over the singer's identifications are performative because they involve the entextualization of sedimented discourses but also new meanings in friction. Closely linked to the performative dimension of language, the phenomenon of entextualization signals that, in the repetition of texts which have become ossified in culture, new meanings are born, given that, in the process of recontextualization, texts always acquire new meaningful nuances. In this discursive action, Luan is compelled to respond to the dominant common 
sense social race performative, which presupposes the existence of a 'true' race and of a specific manner of being this race, under the white gaze. Such a position implies that under other gazes alternative meanings for blackness are possible.

While he negotiates valid meanings in this discursive practice, Luan simultaneously constructs his own race identifications. He aligns himself in defense of the singer's performances, opposing arguments which stated that the singer negated his race. In the practice of developing a pedagogic task, Luan racializes the singer's performances as a way of challenging the footings projected about Jackson. In disputing such footings, Luan reaffirms his own positioning as a young black man, who is constantly regulated by hegemonic racial identities. He does so by making recourse to challenging entextualizations of hegemonic race discourses, which signal alternative dimensions for what blacks are like.

\section{A final word}

The objective of this article was the study of how Luan, a focal participant in this research project, constructs his race performances by circulating through different interactional contexts. With this purpose, we observed the entextualization of race discourses on Twitter and at school, focusing in particular on how he dealt with corporeality, normativity matrices, social stereotypes and marginalized alterities in the negotiation of his identity performances. We aimed at focusing on the performative struggles and on the construction of valid meanings in his discursive practices, paying special attention to what we call creative entextualizations, that is, the gaps Luan finds to reorganize the meanings related to the practices in which he engages himself.

In response to this aim, we may say that Luan's identifications are defined by stereotypes based on crystallized discourses about racial differences, which associate the construction of a relation between blackness-ugliness and blackness-selfnegation, which he challenges. Such a combination puts forward the construction game of Luan's identifications, derived from race as an intelligibility matrix which is brought to light under the constant discipline of black bodies.

In Twitter interactions, Luan is questioned about his race because of the black and white photos he posts. Moreira's enunciations presuppose that Luan posts such photos to come closer to aesthetics standards of white supremacy. In these interactional moves, the question "Hi devil, you have prejudice against yourself, you post black/white photos to look attractive and to negate your color?" (cf. Excerpt (3)) is used by Moreira in reference to the enactment of Luan's performances as a young black sensual gay man. Such enunciations point to a macrosocial scale, expressed by the entextualization of sedimented and hierarchized discourses, which locate 
the young man's corporeality as inferior. Moreira entextualizes crystalized discourses which racialize meanings about beauty and establishes for Luan stigmatized positionings, which socially lower his performances of gender/sexuality and race on Twitter. Luan replies to such discourses by self-racializing himself by means of race affirmative practices, which echo strategic essentialist discourses. The enunciation "I AM PROUD OF BEING BLACK!" (Excerpt (3)) brings about such discourses through an opposing and assertive footing, which Luan makes use of in the appreciation of his race and in the contestation of the discipline over his race performances. Such reflexive stances, which increase discourse friction, makes room for the projection of new meanings.

Hence, it is relevant to draw attention to the innovative performances Luan enacts by challenging pre-figured meanings which create scripts for black bodies, going beyond the essentialist strategic discourses he previously indexed. In the interactional game of constructing participation in the social networks Luan next says that "MY RACE IS MADE WHATEVER WAY I LIKE!" (cf. Excerpt (3)). Now he makes use of creative entextualizations of discourses which disrupt given meanings about who he is. In other words, there is no original for his race identifications.

The analysis also focused on Luan's interactional practices in the school context. By discussing a text brought to class by the writing teacher, Luan once again negotiates meanings about black corporeality, beauty and whitening processes. He does so by entextualizing racialized discourses which interpellate Michael Jackson's race performance enactment. While he negotiates valid meanings in this practice, Luan collectively constructs his race identifications. The young man aligns himself in defense of Michael Jackson' performances, challenging arguments that the singer negated his race. In the construction of his argument, Luan racializes the singer's performances as a way of contesting the footings projected about Michael Jackson. While Luan defends the singer's race performances, he also reaffirms his own position as a black young man, who is regulated by race hegemony eyes, signaling as such alternatives out of given meanings.

According to Butler (1990: 34), the "coherence" and the "continuity" of social subjects are not logical or analytical characteristics of personhood. On the contrary, they are norms of intelligibility socially constituted and maintained. This means that the identifications produced in the performative struggles examined here are modes of constructing a supposedly black corporeality on the basis of ossified discourses about what it means to be black in our white supremacist society. Nevertheless, these discursive practices are always susceptible to failure and to decontextualized citations since repetition is never the same (Pennycook, 2007). In this sense, creative entextualizations may arise bringing about new and unpredictable meanings. Thus, despite the fact that Luan is drowned in stereotypes, he 
challenges and transgresses a racial intelligibility matrix which is constantly operating with a view to monitoring black bodies. In this inter-relation, some ruptures act micropolitically (Foucault, 1979), by creating new meanings about race. These actions may also be understood as an identity alternative politics since they constitute discourse strategies through which the adolescent may construct new social legitimate scripts for his body.

By following the textual trajectories about race generated by Luan in two different social spaces, on Twitter and at school, the study drew attention to how these arenas are performative sites of struggle, which are crucial in the ethnographic observation of the meanings which guide the everyday practices of a lot of youngsters. The analysis of these two discursive practices make visible relevant issues related to the production, circulation and interpretation of race meanings in contemporary life in which innovative identity performances co-occur with essentialist ones in struggles about who we are.

Besides this, the identifications and the alignments in relation to the defense of Michael Jackson's race performances at school are strongly related to the discursive struggles which Luan enacts on his online interactions, as seen above. This is one of the aspects in which we are interested in the observation of Luan's identity performances because it shows how the experience of the construction of his black corporeality is produced in the struggles of different social voices and of multiple discursive identity intersections. It was therefore possible to see how the texts produced by Luan both on Twitter and at school are fully inter-related.

Through this multi-situated ethnographic piece of research, we hope to have pointed to and exemplified how people in their contemporary translocal lives may increasingly have the possibility of contesting essentialist meanings and of rewriting who they are or may be, despite the existence of counter-discourses. This has been made possible because the design of this research tries to capture how in globalized spaces people are more and more living their lives by overcoming the limits of a single space and making meaning-connections across a potential infinite number of diversified interactional and discursive practices. These connections allow us to glimpse how apparently different and distant phenomena are connected through several knots in the construction of translocal meanings. Such a glimpse, on its turn, implies the need of revising the localized theoretical-analytical categories and research designs which have traditionally defined the agenda of language applied studies. It is to the hope of opening the doors for another way of observing interactional practices which are increasingly translocal and constitutive of our mobile world that this study may contribute.

Furthermore, in the last analysis, this study highlights how so-called 'periphery' meanings are to an increasing degree translocal and can only be approached in the flow of social life, as done here. The mobile life in the 'periphery' focused on 
in this article may be referred to as representative of what Souza Santos (2008: 32) has defined as "subaltern cosmopolitanism", or, as we prefer, as "alternative cosmopolitanism", which in a counter-hegemonic globalization perspective explodes the traditional boundaries between 'center' and 'periphery'. This explosion is made visible in the mobile practices through online /offline social networks in which Luan calls the meanings about who he is into being here and now.

\section{References}

Appadurai, A. (1996). Modernity at large: Cultural dimensions of globalization. Minneapolis, MN: University of Minnesota Press.

Barnard, I. (2004). Queer race. Bern: Peter Lang.

Bauman, R., \& Briggs, C. (1990). Poetics and performance as critical perspectives on language and social life. Annual Review of Anthropology, 19, 59-88. doi:10.1146/annurev.an.19.100190.000423

Bhabha, H. (2007[1994]). O local da cultura, trans. M. Ávila, E. Lourenço \& R. Gláucia. Belo Horizonte: Ed. UFMG.

Blommaert, J. (2005). Discourse. Cambridge: Cambridge University Press. doi: $10.1017 /$ CBO9780511610295

Blommaert, J. (2010). The sociolinguistics of globalization. Cambridge: Cambridge University Press. doi:10.1017/CBO9780511845307

Blommaert, J., \& Maly, I. (2014). Ethnographic linguistic landscape analysis and social change: A case study. Tilburg Papers in Culture Studies, 100, 1-28. Tilburg: Tilburg University.

Blommaert, J., \& Rampton, B. (2011). Language and superdiversity: A position paper. Working Papers in Urban Language \& Literacies, 70(14): 1-22. King's College London.

Bucholtz, M. (2000). The politics of transcription. Journal of Pragmatics, 32, 1439-1465. doi:10.1016/S0378-2166(99)0o094-6

Butler, J. (1990). Gender trouble: Feminism and the subversion of identity. New York, NY: Routledge.

Collins, J. (2011). Indexicalities of language contact in an era of globalization: Engaging with John Gumperz's legacy. Text \& talk, 31(4), 407-428. doi:10.1515/text.2011.020

Costa de Paula, R. (2010). "Não quero ser branca não. Só quero um cabelo bom, cabelo bonito!" Performances de corpos/cabelos de adolescentes negras em práticas informais de letramento. Unpublished PhD dissertation, UNICAMP (State University of Campinas, Brazil).

Foucault, M. (1979). Microfísica do poder, trans. R. Machado. Rio de Janeiro: Graal.

Goffman, E. (2002[1979]). Footing. In B. T. Ribeiro \& Garcez, P. M. (Eds.), Sociolinguística interacional: Antropologia, linguística e sociologia em análise do discurso (pp. 107-148). Porto Alegre: AGE.

Guimarães, A. S. (2003). Como trabalhar com "raça" em sociologia. Educação e Pesquisa, 29(1), 93-107. doi: 10.1590/S1517-97022003000100008

Guimarães, T. F. (2014). Embates entre performances corpóreo-discursivas em trajetórias textuais: uma etnografia multissituada. Unpublished $\mathrm{PhD}$ dissertation, The Federal University of Rio de Janeiro, Brazil. 
Guimarães, T. F., \& Moita-Lopes, L. P. (2016). Entextualizações estratégicas: Performances sensualizadas de raça em práticas discursivas na web 2.0. Linguagem em (Dis)curso, 16(2): 289-307.

Gumperz, J. (2002[1982]). Convenções de contextualização. In B. T. Ribeiro \& P. M. Garcez (Eds.), Sociolinguística Interacional: Antropologia, linguística e sociologia em análise do discurso (pp. 98-119). Porto Alegre: AGE.

Marcus, G. E. (1995). Ethnography in/of the world system. The emergence of multi-sited ethnography. Annual Review of Anthropology, 24, 95 - 117.

doi:10.1146/annurev.an.24.100195.000523

Pennycook, A. (2007). Global Englishes and transcultural flows. London: Routledge.

Preciado, B. (2010). Entrevista com Beatriz Preciado. Revista Poiésis, 15, 47-71.

Souza Santos, B. (2008). Do pós-moderno ao pós-colonial. E para além de um e de outro. Travessias, 7(6), 15-36.

Silverstein, M., \& Urban, G. (Eds.). (1996). Natural histories of discourse. Chicago, IL: The University of Chicago Press.

Sommerville, S. B. (2000). Queering the color line: Race and the inventions of homosexuality in American culture. Durham, NC: Duke University Press.

Sullivan, N. (2003). A critical introduction to queer theory. New York, NY: New York University Press.

Varis, P., \& Blommaert, J. (2014). Conviviality and collectives on social media: Virality, memes, and new social structures. Tilburg Papers in Culture Studies, 108, 1-21.

Wittel, A. (2000). Ethnography on the move: From field to net to internet. Forum: Qualitative Social Research, 1(1): 21-41.

Wortham, S. (2006). Learning identity: The joint emergence of social identification and academic learning. Cambridge: Cambridge University Press.

Appendix Transcription conventions (adapted from Bucholtz, 2000)

(.) less than a second pause

CAPITALS higher volume

$>$ text $<\quad$ accelerated speech

((text)) scene notations

text emphasis

?

@@@

slight rise in intonation

quicker rise in intonation

laughter

rising intonation

speech $=\quad$ contiguous speech turn 